\title{
Pigment composition, glutathione and tocopherols in green algal and cyanobacterial lichens and their response to different light treatments
}

\author{
Hana Cempírková*, Kristýna Večeřová
}

Department of Experimental Biology, Masaryk University, Kotlářská 2, 61137 Brno, Czech Republic

\begin{abstract}
This study investigated photosynthetic pigments chlorophyll $a$ and $b$, carotenoids (including xanthophyll cycle pigments) and antioxidants glutathione and tocopherols contents in chloro- (Lobaria pulmonaria, Lasallia pustulata) and cyanolichens (Lobaria scrobiculata, Peltigera canina) from different habitats and of different geographical origin. Lichen thalli were treated with various levels of irradiance (from 100 to $1500 \mu \mathrm{mol}$ $\mathrm{m}^{-2} \mathrm{~s}^{-1}$ ) for various time periods (from $20 \mathrm{~min}$. to $5 \mathrm{~h}$ ). The extent of increase of zeaxanthin content after different light treatments differed among chlorolichens, clearly distinguishing the species from light and shade habitats. Irrespective of light treatment, $\beta$-carotene content was always higher in cyanobacterial species than in green algal species. Highest canthaxanthin concentration, as well as $\beta$-carotene concentration, was found in L. scrobiculata from shade habitat. The content of total glutathione was the same in the same species from different collection sites. On the contrary, contents of $\alpha$-tocopherol differed in the same species from different collection sites.
\end{abstract}

Key words: excess light stress, antioxidants, photoprotection, zeaxanthin

Abbreviations: GSH - Glutathione, ROS - Reactive oxygen species, VAZ - xanthophyll cycle pigments pool

DOI: $10.5817 / \mathrm{CPR} 2018-2-17$

\section{Introduction}

Lichens, i.e. photosynthetic organisms consisting of fungal mycobiont and a green algal or cyanobacterial photobiont, thanks to their adaptive strategies, may grow and thrive at extremely different light environments. The occupy a great variety of habi-

Received May 16, 2018, accepted December 10, 2018.

"Corresponding author: H. Cempírková <cempirkova@sci.muni.cz>

Acknowledgements: This research was supported by the Project No. 206/06/P209 of the Grant Agency of the Czech Republic. 
tats from deep shade niches in rainforest to light-exposed rocks in open mountain habitats.

Photoprotection of lichens against excessive light co-acts with hydration status of their thalli. In a dry state, the main barrier formed by secondary metabolites is produced by the mycobiont, e.g. parietin (Solhaug et Gauslaa 1996) or melanins (Gauslaa et Solhaug 2001). Furthermore, curling of thalli may act as effective protection of sensitive photobionts (Barták et al. 2006). Nevertheless, in hydrated state, the excess light passes through mycobiont cortex to deeper placed photobionts very easily.

In lichens, algal and/or cyanobacterial photobionts protect themselves against excess light by several mechanisms. In chlorolichens, xanthophyll cycle is used as an effective defense strategy against the harmful effect of the absorbed excess light. The xanthophyll cycle is a general photoprotective mechanism since it is present in higher plants (Demmig-Adams 1990), green algae (Masojídek et al. 1999), as well as in green-algae lichens (Calatayud et al. 1997). Beside its role in xanthophyll cycle, zeaxanthin acts also as an antioxidant. It can scavenge harmful reactive oxygen species (ROS) formed during excess light episodes and protects lipid membranes (Havaux et Niyogi 1999). Lutein, another carotenoid, is also considered as a photoprotective pigment, capable of deactivation of triplet chlorophyll formed as a consequence of PS II overenergization (Dall'Osto et al. 2006) and quenching of singlet chlorophyll (Nyogi et al. 1997).

Cyanolichens may contain, amongst other carotenoids, some amount of zeaxanthin; however, cyanobacteria cannot rapidly change its amount due to lack of xanthophyll cycle. It was hypothesized that cyanobacteria slowly accumulate zeaxanthin during longer periods of light exposure in order to increase radiationless ener- gy dissipation (Shagerl et Muller 2006). Other photoprotective mechanisms have been proposed for cyanolichens, e.g. phycobilisomes-related mechanism with essential role of soluble orange carotenoid protein (Kirilovsky 2007); canthaxanthin also is assumed as one of photoprotective compounds in cyanobacterial lichens (Lange et al. 1999).

Excess light stress excites chlorophyll molecules and generates ROS which in turn can be scavenged by antioxidants. Glutathione (GSH, $\gamma$-glutamyl-cysteinyl-glycine) is one of the most abundant low molecular weight thiol in plant tissues. GSH is a strong reductant, which makes it an effective scavenger of ROS. The ROS detoxification capacity of the glutathione redox system is dependent on the pool size of the total $\mathrm{GSH}$, the ratio of oxidized to total glutathione, and the activity of NADPHdependent glutathione reductase. The role of GSH in the antioxidative defense system of plant cells is of a great importance. It is probable that GSH directly reduces ROS, and, furthermore, it is involved in the regeneration of another antioxidant, ascorbate (Tausz 2001). Tocopherols are considered to be general antioxidants important for protection of membrane stability (Fryer 1992), being able to quench or scavenge the singlet oxygen (Knox et Dodge 1985).

The studies about antioxidants related to photoprotection in lichens are only scarce so far. The aim of this study was to compare chloro- and cyanolichens collected at the sites with different radiation regimen, amount of several pigments and antioxidants involved into photoprotection, respectively. In all the studied species, we analyzed the composition of photosynthetic pigments and selected antioxidants (glutathione and tocopherols), and quantified experimentally induced changes of contents of zeaxanthin. 


\section{Material and Methods}

\section{Lichen material}

Lichen thalli were collected in Norway and in Czech Republic during late March to beginning of April; details on lichen species and collection sites are given in Table 1. After their collection, thalli were dried at room temperature for $24 \mathrm{~h}$ and stored in a refrigerator until the start of ex- periments (for less than one month). Before experiments, the thalli were hydrated by spraying with distilled water, and kept for $48 \mathrm{~h}$ in a fully hydrated state at $17^{\circ} \mathrm{C}$ under irradiance of $20-30 \mu \mathrm{mol} \mathrm{m} \mathrm{m}^{-2} \mathrm{~s}^{-1}$ of photosynthetically active radiation to ensure full restoration of photosynthetic processes.

\begin{tabular}{|c|c|c|c|c|c|}
\hline Lichen species & Photobiont & Collection site & $\begin{array}{l}\text { Geograph- } \\
\text { ical origin }\end{array}$ & Coordinates & Habitat \\
\hline $\begin{array}{l}\text { Lobaria pulmonaria } \\
\text { (L.) Hoffm. }\end{array}$ & $\begin{array}{l}\text { Dictyo- } \\
\text { chloropsis }(G)\end{array}$ & $\begin{array}{l}\text { Nord-Trøndelag, } \\
\text { Overhalla, Horka }\end{array}$ & Norway & $\begin{array}{l}\text { N } 64^{\circ} 26^{\prime} 37^{\prime \prime} \\
\text { E } 11^{\circ} 46^{\prime} 49^{\prime \prime}\end{array}$ & $\begin{array}{l}\text { corticolous on } \\
\text { Alnus } \text { sp. and } \\
\text { Salix caprea } \\
\text { in Picea abies } \\
\text { forest }\end{array}$ \\
\hline $\begin{array}{l}\text { Lobaria scrobiculata } \\
\text { (Scop.) DC }\end{array}$ & Nostoc (C) & $\begin{array}{l}\text { Nord-Trøndelag, } \\
\text { Overhalla, Horka }\end{array}$ & Norway & $\begin{array}{l}\text { N } 64^{\circ} 26^{\prime} 37^{\prime \prime} \\
\text { E } 11^{\circ} 46^{\prime} 49^{\prime \prime}\end{array}$ & $\begin{array}{l}\text { corticolous on } \\
\text { Alnus sp. and } \\
\text { Salix caprea } \\
\text { in Picea abies } \\
\text { forest }\end{array}$ \\
\hline $\begin{array}{l}\text { Lasallia pustulata } \\
\text { (L.) Mérat }\end{array}$ & Trebouxia $(G)$ & $\begin{array}{l}\text { near castle } \\
\text { Veveří, Brno } \\
\text { dam }\end{array}$ & $\begin{array}{l}\text { Czech } \\
\text { Republic }\end{array}$ & $\begin{array}{l}\text { N } 49^{\circ} 15^{\prime} 19^{\prime \prime} \\
\text { E } 16^{\circ} 27^{\prime} 51^{\prime \prime}\end{array}$ & $\begin{array}{l}\text { sun-exposed } \\
\text { on north-west } \\
\text { facing rocks }\end{array}$ \\
\hline $\begin{array}{l}\text { Lasallia pustulata } \\
\text { (L.) Mérat }\end{array}$ & Trebouxia $(G)$ & $\begin{array}{l}\text { Akershus, Aas, } \\
\text { Kinn }\end{array}$ & Norway & $\begin{array}{l}\text { N } 59^{\circ} 40^{\prime} 85^{\prime \prime} \\
\text { E } 10^{\circ} 45^{\prime} 40^{\prime \prime}\end{array}$ & $\begin{array}{l}\text { sun-exposed } \\
\text { on west facing } \\
\text { rocks }\end{array}$ \\
\hline $\begin{array}{l}\text { Peltigera canina } \\
\text { (L.) Willd }\end{array}$ & Nostoc (C) & $\begin{array}{l}\text { on shore of Brno } \\
\text { dam }\end{array}$ & $\begin{array}{l}\text { Czech } \\
\text { Republic }\end{array}$ & $\begin{array}{l}\text { N } 49^{\circ} 15^{\prime} 34^{\prime \prime} \\
\text { E } 16^{\circ} 27^{\prime} 33^{\prime \prime}\end{array}$ & $\begin{array}{l}\text { among } \\
\text { bryophytes on } \\
\text { west facing } \\
\text { rocks }\end{array}$ \\
\hline $\begin{array}{l}\text { Peltigera canina } \\
\text { (L.) Willd }\end{array}$ & Nostoc (C) & $\begin{array}{l}\text { Akershus, Aas, } \\
\text { Kinn }\end{array}$ & Norway & $\begin{array}{l}\text { N } 59^{\circ} 40^{\prime} 70^{\prime \prime} \\
\text { E } 10^{\circ} 45^{\prime} 80^{\prime \prime}\end{array}$ & $\begin{array}{l}\text { among } \\
\text { bryophytes on } \\
\text { east facing } \\
\text { rock }\end{array}$ \\
\hline
\end{tabular}

Table 1. List of the lichen species studied, and details on their collection sites. Notes: G - green algae, $\mathrm{C}$ - cyanobacteria.

\section{Experimental setup}

After pre-treatment (see above), the lichen thalli were randomly divided into several groups, each having about 5-7 thalli. Each group was exposed to different light treatment (for details, see Table 2). The treatments were chosen in order to test reciprocity of exposure time and level of light intensity. Individual treatments differed in time of exposure and light intensity; high light exposures were shorter whereas low light exposures took prolonged time, resulting in similar total irradiance quantity at the end of each exposure. Different light intensities were achieved by a LED source (UTEE, Technical University Brno, Czech Republic) composed of 17 superbright white 
warm LEDs (Luxeon Warm-White, Philips Lumileds, USA) providing a continuous spectrum. Temperature of the lichen thalli during light treatments was kept at $20^{\circ} \mathrm{C}$. The thalli were kept fully hydrated. After the light exposures, the thalli were immediately frozen in liquid nitrogen. Afterwards, they were kept in a freezer until the end of all experiments (for less than 3 weeks) and then they were freeze-dried.

\begin{tabular}{|c|c|c|}
\hline 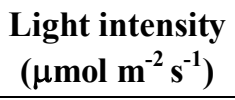 & Time of light exposure & $\begin{array}{c}\text { Abbreviation used in } \\
\text { text }\end{array}$ \\
\hline 1500 & $20 \mathrm{~min}$. & $1500 / 20$ \\
\hline 1000 & $30 \mathrm{~min}$. & $1000 / 30$ \\
\hline 500 & $50 \mathrm{~min}$. & $500 / 50$ \\
\hline 100 & $5 \mathrm{~h}$ & $100 / 5$ \\
\hline $100+1000$ & $5 \mathrm{~h}(100)+30 \min .(1000)$ & $100+1000$ \\
\hline
\end{tabular}

Table 2. Light intensities and light exposure durations.

\section{Photosynthetic pigments and antioxidants determination}

In order to reduce undesirable reaction of lichen secondary compounds during the extraction of pigments and antioxidants, the secondary compounds contained in mycobiont cortex were extracted by $100 \%$ acetone from freeze-dried thalli (Solhaug et Gauslaa 2001). After the evaporation of residual acetone, the thalli were grinded in a ball mill into fine powder. Grinded lichen thalli were kept at $-20^{\circ} \mathrm{C}$ until analysis.

Each sample of lichen thallus powder was divided into two parts: one for photosynthetic pigments and tocopherols analysis, second for glutathione determination.

For pigment analysis, approximately $60 \mathrm{mg}$ of lichen powder was mixed with $100 \%$ acetone with addition of $\mathrm{CaCO}_{3}$. Small glass balls were added to improve sample homogenization and thus facilitate the extraction of pigments. Resulting ex- tracts were analyzed by a HPLC (Waters, USA) using freshly prepared (on TLC neoxanthin, violaxanthin, lutein) and commercial standards (chlorophyll $a$, chlorophyll $b$, zeaxanthin, $\beta$-carotene, canthaxanthin). For details on the HPLC analysis, see Stepigová et al. (2007).

Approximately $60 \mathrm{mg}$ of lichen powder was used for quantification of glutathione according to method described by Kranner (1998). Glutathione was separated and quantified by reversed-phase HPLC (Waters, USA) using a fluorescence detector (see Štepigová et al. 2007).

Tocopherols ( $\alpha$-, $\gamma$ - and $\delta$-) were determined and quantified in the acetone extracts by HPLC (Waters, USA) using commercial standards according to Pfeifhofer et al. (2002).

\section{Statistical analysis}

Data were analyzed by one-way ANOVA in combination with a LSD test to evaluate statistically significant differences $(\mathrm{p}<0.05)$. 


\section{Results}

Before the light treatments, zeaxanthin contents and xanthophyll cycle pigments pool (VAZ) in green algae lichens did not differ significantly (Fig. 1, Table 3). All light treatments led to an increase of zeaxanthin contents in all studied chlorolichens but the increase was statistically insignificant in L. pulstulata thalli from Czech Republic (Fig. 1). However, interspecific differences were found. L. pulmonaria thalli exhibited a significant increase of zeaxanthin content after 100/5 treatment whereas the treatment did not cause any significant increase in zeaxanthin in the L. pustulata thalli. On the other hand, $100+1000$ treatment led to a significant increase of zeaxanthin in both L. pulmonaria and L. pustulata from Norway. The zeaxanthin content increase after the all types of light treatment was substantially lower in L. pustulata from Czech Republic than in L. pustulata from Norway.

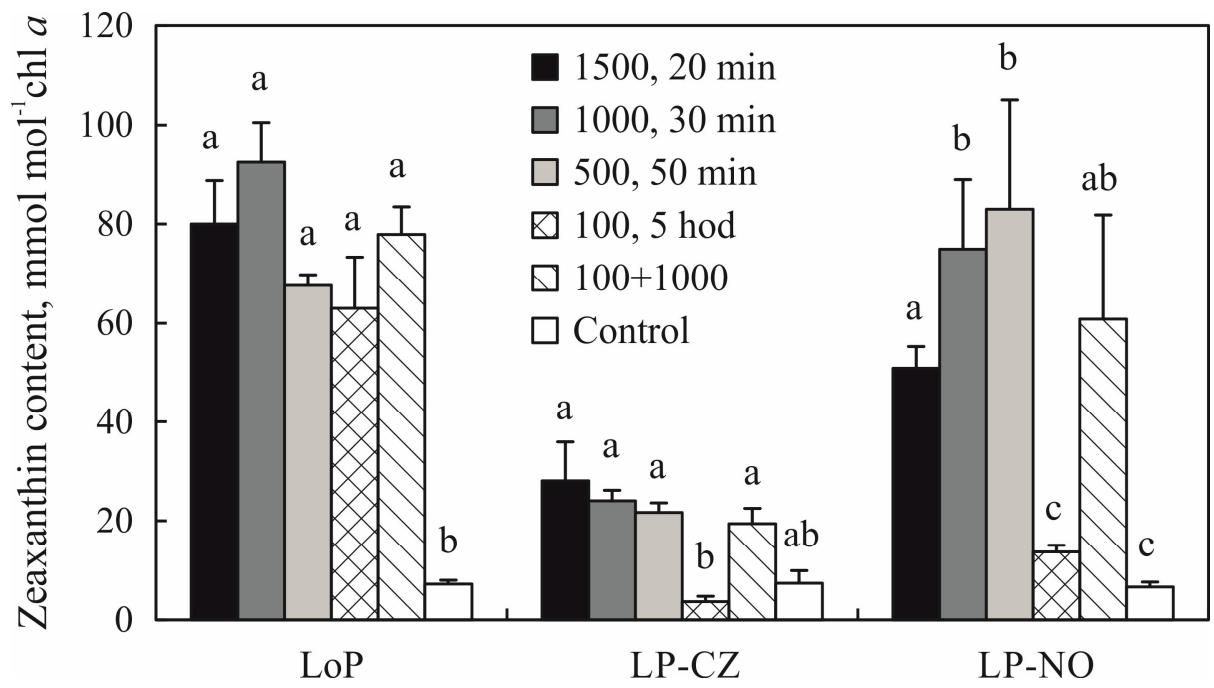

Fig. 1. Zeaxanthin contents in control thalli and in thalli exposed to different light treatments. The values represent means of 4-7 replicates $\pm \mathrm{SE}$. LoP - L. pulmonaria, $\mathrm{LP}-\mathrm{CZ}-$ L. pustulata from Czech Republic, LP-NO - L. pustulata from Norway. Characters $(\mathrm{a}, \mathrm{b}, \mathrm{c})$ denote statistically significant difference $(0.05)$ related to different light treatment effects in a single lichen species.

$\beta$-carotene concentrations were higher in cyanolichens than in green-algae lichens (Table 3). On the contrary, neoxanthin and lutein concentrations were very low in cyanolichens compared to green-algae lichens. The highest $\beta$-carotene concentrations were found in the shade-habitat cyanolichen species L. scrobiculata. In chlorolichens, the shade-habitat species L. pulmonaria contained significantly lower $\beta$-carotene con- tents compared to lichen thalli of $L$. pustulata from sun-exposed habitats.

The highest canthaxanthin and $\beta$-carotene concentrations were found in L. scrobiculata from shade habitat. Both canthaxanthin and $\beta$-carotene concentrations in $P$. canina from Czech Republic were higher compared to those in $P$. canina from Norway (Table 3). 


\begin{tabular}{|c|c|c|c|c|c|c|c|c|}
\hline 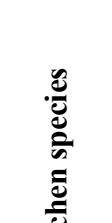 & 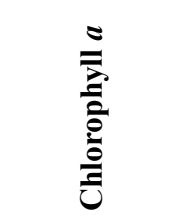 & 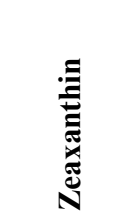 & & $\sum_{2}^{2}$ & 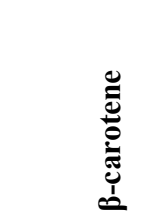 & 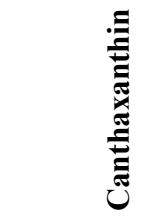 & 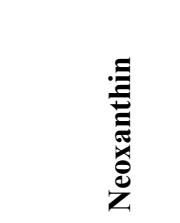 & \\
\hline ב & $\left(\mu \mathrm{g} \mathrm{g}^{-1} \mathrm{DW}\right)$ & \multicolumn{7}{|c|}{$\left(\mathrm{mmol} \mathrm{mol}{ }^{-1} \operatorname{chl} a\right)$} \\
\hline LoS & $\begin{array}{r}406.91 a \\
\pm 22.24\end{array}$ & $\begin{array}{r}\mathbf{1 6 . 4 0} \\
\pm 4.73\end{array}$ & & - & $\begin{array}{r}\mathbf{3 7 8 . 9 9} \\
\pm 18.82\end{array}$ & $\begin{array}{rr}a & \mathbf{1 3 5 . 4 0} \\
& \pm 10.84\end{array}$ & $\begin{array}{r}1.27 a \\
\pm 0.22\end{array}$ & $\begin{array}{r}\mathbf{3 . 4 9} \\
\pm 0.33\end{array}$ \\
\hline $\mathrm{PC}-\mathrm{CZ}$ & $\begin{array}{r}\mathbf{6 4 4 . 6 7} b \\
\pm 25.41\end{array}$ & $\begin{array}{r}9.65 \\
\pm 0.39\end{array}$ & $a$ & - & $\begin{array}{c}\mathbf{2 5 7 . 7 2} \\
\pm 7.90\end{array}$ & $\begin{array}{r}b \quad \mathbf{7 4 . 5 9} \\
\quad \pm 5.43\end{array}$ & $\begin{array}{r}1.21 a \\
\pm 0.15\end{array}$ & $\begin{array}{r}\mathbf{2 . 2 7} \\
+0.27\end{array}$ \\
\hline PC-NO & $\begin{array}{r}\mathbf{6 9 4 . 0 1} b \\
\pm 33.68\end{array}$ & $\begin{array}{r}\mathbf{9 . 2 4} \\
\pm 0.42\end{array}$ & $a$ & - & $\begin{array}{c}204.92 \\
\pm 3.83\end{array}$ & $\begin{array}{r}\mathbf{5 6 . 0 3} \\
\pm 4.79\end{array}$ & $\begin{array}{r}1.14 a \\
\pm 0.12\end{array}$ & $\begin{array}{r}\mathbf{1 . 6 3} \\
\pm 0.20\end{array}$ \\
\hline LoP & $\begin{array}{r}\mathbf{9 3 3 . 3 2} c \\
\pm 44.76\end{array}$ & $\begin{array}{r}7.17 \\
\pm 0.79\end{array}$ & $b$ & $\begin{array}{c}\mathbf{2 2 9 . 1 2} a \\
\pm 9.28\end{array}$ & $\begin{array}{r}\mathbf{8 2 . 1 3} \\
\pm 0.98\end{array}$ & $d$ & $\begin{array}{c}\mathbf{1 0 4 . 7 6} \\
\pm 1.28\end{array}$ & 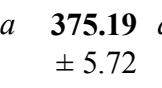 \\
\hline LP-CZ & $\begin{array}{r}339.96 a \\
\pm 19.54\end{array}$ & $\begin{array}{r}7.35 \\
\pm 2.55\end{array}$ & $a$ & $\begin{array}{r}\mathbf{2 4 8 . 8 7} \\
\pm 12.78\end{array}$ & $\begin{array}{c}\mathbf{1 3 4 . 6 1} \\
\pm 6.10\end{array}$ & $e$ & $\begin{array}{c}\mathbf{1 3 4 . 6 4} b \\
\pm 4.78\end{array}$ & $\begin{array}{r}\quad \mathbf{5 4 1 . 0 5} \\
\pm 20.63\end{array}$ \\
\hline LP-NO & $\begin{array}{r}\mathbf{4 6 2 . 4 8} a \\
\pm 42.32\end{array}$ & $\begin{array}{r}\mathbf{6 . 6 5} \\
\pm 0.95\end{array}$ & c & $\begin{array}{r}\mathbf{2 8 3 . 2 6} a \\
\pm 21.01\end{array}$ & $\begin{array}{r}179.38 \\
\pm 13.73\end{array}$ & $c$ & $\begin{array}{l}\mathbf{1 7 1 . 3 7} c \\
\pm 9.63\end{array}$ & $\begin{array}{r}\mathbf{7 2 4 . 7 5} \\
\pm 47.98\end{array}$ \\
\hline
\end{tabular}

Table 3. Average contents of chlorophyll $a\left(\mu \mathrm{g} \mathrm{g}^{-1} \mathrm{DW}\right)$, zeaxanthin, total xanthophyll cycle pigments pool (VAZ), $\beta$-carotene, canthaxanthin, neoxanthin, and lutein $\left(\mathrm{mmol} \mathrm{mol}^{-1} \mathrm{chl} a\right)$ in the studied lichen species. The values for zeaxanthin concentration of green-algae lichens represent means of 5 replicates of control thalli (before light treatments) \pm standard error (SE). All other values did not change during the light treatments and represent means of at least 30 replicates (all thalli used in the experiment) $\pm \mathrm{SE}$. LoS - L. scrobiculata, PC-CZ $-P$. canina from Czech Republic, PC-NO - P. canina from Norway, LoP - L. pulmonaria, LP-CZ - L. pustulata from Czech Republic, LP-NO - L. pustulata from Norway. Notes: Characters (a - f) denote statistically significant difference $(0.05)$ in values between species.

While neoxanthin and lutein concentration in cyanolichens did not differ among the studied samples, they were significantly different in chlorolichens.

Total glutathione contents (GSH) did not change after any of the light treatments compared to the control samples. Contents of glutathione differed among the species (Fig. 2), with the highest values in L. pustulata and the lowest values in P. canina. However, contents of total glutathione were the same in identical species from different collection sites.

The lichen thalli of the studied species contained significant amounts of $\alpha$ - and $\gamma$ tocopherol. Zero contents of $\delta$-tocopherol were observed in all of the species (Fig. 3).

The contents of $\alpha$-tocopherol were comparable in cyanobacterial and chlorolichens, ranging approximately from 30 to $50 \mu \mathrm{g} \mathrm{g}^{-1}$ DW. In cyanobacterial lichens, contents of $\alpha$-tocopherol were higher in $P$. canina from Czech Republic than in $P$. canina from Norway. In green chlorolichens, however, L. pustulata from Czech Republic contained less $\alpha$-tocopherol than L. pustulata from Norway. When comparing the lichen species from the same collection site, the cyanolichen L. scrobiculata had higher content of $\alpha$-tocopherol than the chlorolichen L. pulmonaria. 


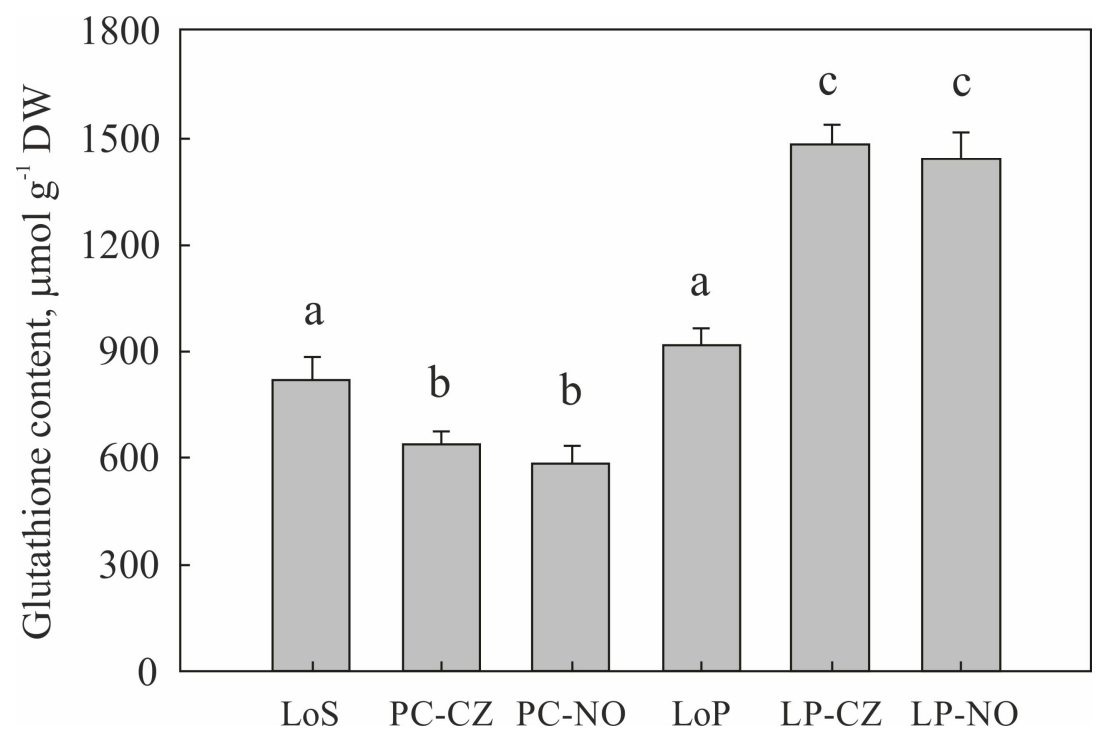

Fig. 2. Total glutathione contents in the studied lichen species. The values are means of thalli from all light treatments (as the contents did not differ among the treated samples) and represent at least 9 replicates \pm SE. LoS - L. scrobiculata, PC-CZ - P. canina from Czech Republic, PC-NO P. canina from Norway, LoP - L. pulmonaria, LP-CZ - L. pustulata from Czech Republic, LP-NO - L. pustulata from Norway. Characters $(\mathrm{a}, \mathrm{b}, \mathrm{c})$ denote statistically significant difference $(0.05)$ in values between species.

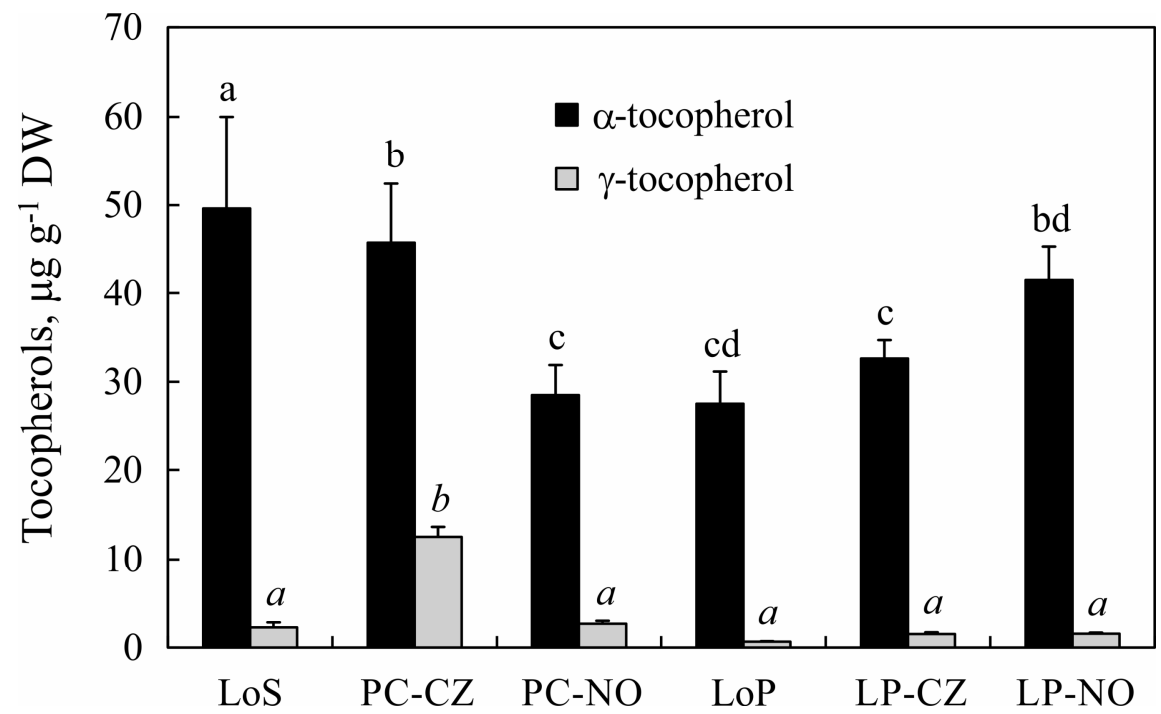

Fig. 3. Contents of $\alpha$ - and $\gamma$-tocopherol in the studied species. The values represent means of at least 5 replicates $\pm \mathrm{SE}$. LoS $-L$. scrobiculata, PC-CZ $-P$. canina from Czech Republic, PC-NO - P. canina from Norway, LoP - L. pulmonaria, LP-CZ - L. pustulata from Czech Republic, LP-NO - L. pustulata from Norway. Characters denote statistically significant difference $(0.05)$ in $\alpha$-tocopherol $(\mathrm{a}, \mathrm{b}, \mathrm{c})$ and $\gamma$-tocopherol $(a, b, c)$ values between species. 


\section{Discussion}

Photoprotective pigments are known to response rapidly along with changing light conditions; however, only zeaxanthin responds to acute, short-term light stress (lasting tens of minutes; e.g. Vráblíková et al. 2005). In our study, zeaxanthin response differed between shade- and lightadapted species. L. pulmonaria, a species from deciduous forest, responded by an increased zeaxanthin formation to all of the light treatments, whereas L. pustulata thalli from light-exposed rocks did not respond by a significant zeaxanthin increase to the lowest light treatment $\left(100 \mu \mathrm{mol} \mathrm{m}{ }^{-2}\right.$ $\mathrm{s}^{-1}$ for $5 \mathrm{~h}$; see Fig. 1). This suggests that L. pustulata (from both Czech Republic and Norway) has a higher capacity of photoprotective mechanisms than L. pulmonaria. Such explanation might be supported by higher $\beta$-carotene, lutein, tocopherol and glutathione contents in L. pustulata (see Fig. 2). At the same time, L. pustulata from Czech Republic showed a significantly less extensive zeaxanthin increase and lower $\beta$-carotene, lutein and tocopherol contents than the same species from Norway (Fig. 1). This demonstrates a higher photoprotective mechanisms capacity in L. pustulata from the Norway, most likely due to previous high light exposure and/or other climatic conditions on the collection site (e.g. Piccotto et Tretiach 2010).

$P$. canina from Czech Republic had a higher photoprotective capacity than $P$. $c a-$ nina from Norway. This is indicated by canthaxanthin contents. Dynamics of canthaxanthin formation was demonstrated by Leisner et al. (1994) who found a significant increase in canthaxanthin concentration after the exposure of Peltigera species thalli to high light for 5 days. These data are supported also by higher tocopherol contents found in P. canina from Czech Republic than $P$. canina from Norway. For several different cyanolichens, Leisner et al. (1994) showed that $\beta$-carotene increases and canthaxanthin decreases with decreasing light in habitat. Our data are not consistent with their findings, because in our study, L. scrobiculata from shade habitat had higher $\beta$-carotene as well as higher canthaxanthin contents than sun-exposed P. canina.

Higher glutathione concentrations seem to improve protection against environmental stresses (Tausz et al. 2004). The highest glutathione content in our study was found in L. pustulata, a chlorolichen from sunexposed rocks. On the other hand, sunadapted cyanolichens $P$. canina had the lowest GSH content, even lower than in the cyanolichen L. scrobiculata from a deciduous forest. Moreover, GSH did not differ between the thalli from different collection sites, even though other measured data suggested higher photoprotective capacity of thalli from Norway. Total glutathione content did not change after any of light treatments compared to control. In our previous study (Vráblíková et al. 2005), total glutathione content in Umbilicaria antarctica and L. pustulata significantly decreased after short-term high light treatment. The initial decrease of GSH could be a result of rapid, acute high light stress that caused light-dependent degradation of GSH. Therefore, we can assume that the stress caused by our experiments was compensated by other protective mechanisms than glutathione, e.g. xanthophyll cycle pigments. Similar results were reported also by Balarinová et al. (2014), who exposed lichen thalli (Usnea antarctica and Usnea aurantiaco-atra) to medium light stress $\left(800 \mu \mathrm{mol} \mathrm{m} \mathrm{m}^{-2} \mathrm{~s}^{-1}\right.$ for $\left.1 \mathrm{~h}\right)$ and did not observe any degradation of GSH caused by the light exposure.

In photosynthetic organisms, tocopherol levels are elevated in response to a variety of abiotic stresses, including excessive light (e.g. Müller-Moulé et al. 2003). It is well established that concentration of to- 
copherols in plants and algae increases in long-lasting high light conditions (Trebst et al. 2002, Garcia-Plazaola et al. 2004). In our study, the amounts of tocopherols are in good agreement with $\alpha$-tocopherol contents found in other lichen species (e.g. Strzalka et al. 2011) and did not change after excess light treatments. The likely explanation is that because their concentrations would possibly change only after longer exposition of thalli to excess light; the same results were observed by e.g. Kobayashi et DellaPenna (2008). According to Garcia-Plazaola et al. (2004), $\alpha$-tocopherol is the key antioxidant altering tolerance to high light, and it may cooperate with zeaxanthin. High light exposure leads to high $\alpha$-tocopherol concentration, which is correlated with high xanthophyll cycle pool (VAZ). In our study, we found similar results. In the lichen thalli with high VAZ concentration, the $\alpha$-tocopherol concentration was also high. L. pustulata from
Norway contained more tocopherol and exhibited higher zeaxanthin increase after light treatments, as well as higher content of other carotenoids than L. pustulata from Czech Republic. The similar results were found also in cyanobacterial species. Higher content of carotenoids in L. scrobiculata than in $P$. canina was accompanied with higher content of $\alpha$-tocopherol in the former species. Also Kranner et al. (2003) observed high $\beta$-carotene and tocopherol content in cyanolichen.

We conclude that antioxidant responses are mostly species-specific and highly influenced by habitat and previous conditions in the environment. The antioxidant contents resulting from high light stress were strongly influenced by the long-term stress exposure of respective species; in other words, the species that suffered high levels of light exposure in their natural environments were more resistant to high light stress during the experiments.

\section{References}

Barták, M., Solhaug, K. A., VráblíkovÁ, H. and GauslaA, I. (2006): Curling during desiccation protects the foliose lichen Lobaria pulmonaria against photoinhibition. Oecologia, 149: 553-560.

Balarinová, K., Barták, M., Hazdrová, J., Hájek, J. and Jílková, J. (2014): Changes in photosynthesis, pigment composition and glutathione contents in two Antarctic lichens during a light stress and recovery. Photosynthetica, 52: 538-547.

Calatayud, A., Deltoro, V. I., Barreno, E. and del Valle-Tascon, S. (1997): Changes in in vivo chlorophyll fluorescence quenching in lichen thalli as a function of water content and suggestion of zeaxanthin-associated photoprotection. Physiologia Plantarum, 101: 93-102.

Dall'Osto, L., Lico, C., Alric, J., Giuliano, G., Havaux M. and Bassi, R. (2006): Lutein is needed for efficient chlorophyll triplet quenching in the major LHCII antenna complex of higher plants and effective photoprotection in vivo under strong light. BMC Plant Biology, 6: 32.

DEMmig-AdAms, B. (1990): Carotenoids and photoprotection in plants. A role for the xanthophyll zeaxanthin. Biochimica et Biophysica Acta, 1020: 1-24.

FrYER, M. J. (1992): The antioxidant effects of thylakoid vitamin-E (alpha-tocopherol). Plant, Cell \& Environment, 15: 381-392.

Garcia-Plazaola, J. I., Becerril, J. M., Hernandez, A., Niinemets, U. and Kollist, H. (2004): Acclimation of antioxidant pools to the light environment in a natural forest canopy. New Phytologist, 163: 87-97.

GauslaA, Y., Solhaug, K. A. (2001): Fungal melanins as a sun screen for symbiotic green algae in the lichen Lobaria pulmonaria. Oecologia, 126: 462-471.

HavauX, M., NiYOGI, K. K. (1999): The violoxanthin cycle protects from photoxidative damage by more than one mechanism. Proceedings of the National Academy of Sciences of the United States of America, 96: 8762-8767. 
KIRILOVSKY, D. (2007): Photoprotection in cyanobacteria: the orange carotenoid protein (OCP)related non-photochemical-quenching mechanism. Photosynthesis Research, 93: 7-16.

KNoX, J. P., DoDGE, A. D. (1985): Singlet oxygen and plants. Phytochemistry, 24: 889-896.

KRANNER, I. (1998): Determination of glutathione, glutathione disulphide and two related enzymes, glutathione reductase and glucose-6-phosphate dehydrogenase, in fungal and plant cells. In: A. Varma (ed.): Mycorrhizal Manual. Germany: Springer-Verlag, pp. 227-241.

Kranner, I., Zorn, M., Turk, B., Wornik, S., Beckett, R. R. and BATIC, F. (2003): Biochemical traits of lichens differing in relative desiccation tolerance. New Phytologist, 160(1): 167-176.

Kobayashi, N., DellaPenna, D. (2008): Tocopherol metabolism, oxidation and recycling under high light stress in Arabidopsis. The Plant Journal, 55(4): 607-618.

LANGe, O. L., LeisNer, J. M. R. and BilgeR, W. (1999): Chlorophyll fluorescence characteristics of the cyanobacterial lichen Peltigera rufescens under field conditions II. Diel and annual distribution of metabolic activity and possible mechanisms to avoid photoinhibition. Flora, 194: 413-30.

Leisner, J. M. R., Bilger, W., Czygan, F. C. and LANGe, O. L. (1994): Light exposure and the composition of lipophilous carotenoids in cyanobacterial lichens. Journal of Plant Physiology, 143: 514-519.

Masojídek, J., Torzillo, G., Koblížek, M., Kopecký, J., Bernardini, P., Sacchi, A. and Komenda, J. (1999): Photoadaptation of two members of the Chlorophyta (Scenedesmus and Chlorella) in laboratory and outdoor cultures: changes in chlorophyll fluorescence quenching and the xanthophyll cycle. Planta, 209: 126-135.

Müller-MoulÉ, P., HavauX, M. and NiYogi, K. K. (2003): Zeaxanthin deficiency enhances the high light sensitivity of an ascorbate-deficient mutant of Arabidopsis. Plant Physiology, 133: 748-760.

NiYogi, K. K., BJorkman, O. and Grossman, A. R. (1997): The roles of specific xanthopylls in photoprotection. Proceedings of the National Academy of Sciences of the United States of America, 94: 14162-14167.

Piccotto M., Tretiach M. (2010): Photosynthesis in chlorolichens: the influence of the habitat light regime. Journal of Plant Research, 123(6): 763-775.

Pfeifhofer, H. W., Willfurth, R., Zorn M. and KranNer, I. (2002): Analysis of chlorophylls, carotenoids, and tocopherols in lichens. In: I. Kranner, R. Beckett, A. Varma (eds.): Protocols In Lichenology: Culturing, Biochemistry, Ecophysiology and Use in Biomonitoring. Germany: Springer-Verlag, pp. 363-378.

SCHAGERL, M., MüLLER, B. (2006): Acclimation of chlorophyll a and carotenoid levels to different irradiances in four freshwater cyanobacteria. Journal of Plant Physiology, 163: 709-716.

Solhaug K. A., GauslaA, Y. (1996): Parietin, a photoprotective secondary product of the lichen Xanthoria parietina. Oecologia, 108: 412-418.

Solhaug, K. A., GauslaA, Y. (2001): Acetone rinsing - A method for testing ecological and physiological roles of secondary compounds in living lichens. Symbiosis, 30: 301-315.

ŠTEPIGOVÁ, J., VRÁBlíKOVÁ, H., LANG, J., VeČEŘOVÁ, K. and BARTÁK, M. (2007): Glutathione and zeaxanthin formation during hight light stress in foliose lichens. Plant and Soil Environment, 53: 340-344.

TAuSz, M. (2001): The role of glutathione in plant response and adaptation to natural stress. In: D. Grill, M. Tausz, L. J. de Kok (eds.): Significance of glutathione to plant adaptation to the environment. The Netherlands: Kluwer Academic Publishers, pp. 101-122.

Tausz, M., ŠIrCelJ, H. and GriLl, D. (2004): The glutathione system as a stress marker in plant ecophysiology: is a stress-response concept valid? Journal of Experimental Botany, 55: 19551962.

Trebst, A., Depka, B. and Hollander-CzytKo, H. (2002): A specific role for tocopherol and of chemical singlet oxygen quenchers in the maintenance of photosystem II structure and function in Chlamydomonas reinhardtii. FEBS Letters, 516: 156-160.

VRÁBlíkovÁ, H., BARTÁK, M. and WONISCH, A. (2005): Changes in glutathione and xanthophyll cycle pigments in the high light-stressed lichens Umbilicaria antarctica and Lasallia pustulata. Journal of Photochemistry and Photobiology B: Biology, 79: 35-41. 